\title{
Russet Burbank: No Ordinary Potato
}

\author{
Charles R. Brown ${ }^{1}$ \\ USDA/ARS, WSU-IAREC Horticulture L/A, 24106 N. Bunn Road, Prosser, WA 99350
}

\author{
Additional index words. Burbank, Luther Burbank, hybridization, late blight, 'Early Rose'
}

\begin{abstract}
The 'Russet Burbank' potato cultivar currently occupies first place in acreage planted in North America and is worth in the United States \$1.4 billion annually. It is a sport of 'Burbank's Seedling', which was selected by Luther Burbank in 1873. The ancestry of Burbank stems from a plant introduction brought to the United States by the Rev. Chauncey Goodrich of New York State in 1853. The priorities of potato breeding had been transformed by repetitive crop failures caused by the emergence of the plant pathogen Phytophthora infestans. Modern testing suggests that derivatives of Goodrich's potatoes were slightly more resistant to Phytophthora. Burbank discovered a single fruit on one of these derivatives, 'Early Rose', in his mother's garden. Taking the 23 true seeds, he nursed them to full-sized plants and selected ultimately No. 15. It produced an unusually high yield of large, very oblong tubers, stored well, and was a good eating potato. Burbank's life was destined for a long career in California and he attempted to sell the clone to J.H.J. Gregory of Gregory's Honest Seeds, a successful businessman. Ultimately Gregory agreed to buy it for $\mathbf{\$ 1 5 0}$, far less than Burbank wanted, but enough to propel him to California. Gregory named the potato 'Burbank's Seedling', which no doubt engendered fame for the entrepreneur. Luther Burbank had been allowed by Gregory to keep 10 tubers, which became the seed source for the 'Burbank's Seedling' to spread north and south along the West Coast of North America with a crop value, stated by Burbank, of \$14 million in 1914. It is not clear that Luther Burbank prospered from 'Burbank's Seedling' in the West. A skin sport with a russet skin was found in Colorado in 1902 and was advertised by a seed company under the name 'Netted Gem'. 'Burbank's Seedling' per se disappeared from commerce and 'Netted Gem' slowly increased, finding a special niche in production of French fry potatoes. It is clear that Luther Burbank gained tremendous insight into the dynamics of hybridization in revealing genetic variation from clonally propagated species. During the rest of his career he would use this technique to produce new and amazing forms of numerous food and ornamental species. 'Burbank's Seedling' was his entrez into the world of plant breeding.
\end{abstract}

There are many different plant species where Luther Burbank was responsible for innovative creations. Potato is one of these. Luther Burbank's potato breeding must be seen from an historical perspective. Potatoes were found in South America by Spanish Explorers in the Central Andes. Introduced more as a botanical curiosity $\approx 1570$, the potato appears to have been grown in gardens and recognized as a nutritive food as judged by a letter written by Saint Teresa of Avila, founder of the Barefoot Carmelites, who wrote of their restorative traits when she ate them while in ill health.

In 1843, starting in North America, a mysterious disease began afflicting potato in the northeast of the United States. Two years later, starting on the continent, in Belgium, the same type of fast-moving epidemic started early and then appeared throughout a large area in Ireland (Bourke, 1993). This led to an almost total potato crop failure in 1845 and by the fall of 1846, after another crop failure, an all-encompassing food scarcity. Food stores disappeared in pockets, especially in western Ireland, subsequently vanishing throughout many parts of Ireland. In the previous 55 years, Ireland's population had risen from 2 to 8 million at least partly the result of the success and succor of potato as a crop. Infrastructure was ill-prepared to address famine, and as many thousands of

Received for publication 14 Aug. 2014. Accepted for publication 19 Nov. 2014

This paper was part of the workshop "Contributions of Luther Burbank: Plant Breeding Artist and Legend" held 22 July 2013 at the ASHS Conference, Palm Desert, CA, and sponsored by the ASHS History of Horticultural Science Working Group.

${ }^{1}$ To whom reprint requests should be addressed; e-mail chuck.brown@ars.usda.gov. people died, others, with their last remaining energy, took to the road seeking food. Human diseases appeared, foremost among these cholera. Science understood neither the fast-moving, moisture-loving, air-dispersed late blight nor the drinking waterborne cholera, which vanquished the hunger-debilitated population with spectacular rapidity.

Wherever rumors of food stores emerged, hordes of desperate people would arrive and break into supposed food warehouses. Violence and death ensued, while food became unavailable, at any price in ever widening regions. Meanwhile in England, a debate raged on the appropriate response to the famine. It was one of the first philosophical clashes on the value of welfare to help the poor. There was a prevailing socioreligious standpoint that the massive death occurring in Ireland was an act of God. Above all, harmony had been lost in Ireland and its return was best left to natural processes. When Parliament finally attempted to purchase shiploads of grain for Ireland, the process was much delayed and resulted in a worldwide increase in grain commodity prices (Kelly, 2012).

In the end it is estimated that 1 million Irish perished and 1.5 million emigrated mostly to the United States. Emigration took place during and after the famine. Ireland has yet to recover previous population levels. Perhaps the greatest tragedy of the 19th century, the Irish potato famine was caused by the oomycete Phytophthora infestans. The potato varieties of the time in Ireland were completely susceptible (Salaman, 1949). It still is the most serious disease of potato worldwide.

It was in this context, and considering that potato breeding was in private hands in 1850 , that the Reverend Chauncey Goodrich undertook his calling to fight hunger on receiving potatoes from the Panamanian Consulate, which came with the name "Chili," perhaps denoting the country of origin as Chile. Out of this exotic germplasm Goodrich selected, from openpollinated fruits, first, 'Rough Purple Chili', then 'Garnet Chili', and subsequently another breeder, Albert Bresee, released a seedling derived from 'Garnet Chili', which he named 'Early Rose' (Goodrich, 1863a, 1863b; Plaisted and Hoopes, 1989; Smith, 2009). At this time the greatest goal of plant breeders was to breed varieties more resistant to disease, probably referring to late blight.

The origin of 'Burbank's Seedling', a story filled with unbelievably good fortune, evokes the incredulity of any plant breeder. Luther Burbank as a young man in Massachusetts took on potato as one of his first plant business projects and discovered a fruit in his mother's 'Early Rose' garden patch. This in itself was almost unheard of in the non-fruiting Early Rose cultivar. Carefully marking the fruit, he waited for it to mature. The fruit initially was lost, but was found after 3 full days of searching. Yielding a scant 23 seeds, each of them was carefully germinated and transplanted to his garden. After nurturing each plant to full maturity, he harvested them and made his assessment. Of the 23 seedlings, two were unusual and outstanding. After a second year of propagation, No. 15 was the sole selection, offering an astounding yield of large tubers, good storability, and very good eating quality (Dreyer, 1993). By today's standards the derivatives of Goodrich's potatoes were not particularly resistant as tested in modern resistance trials, but the fact that 'Russet Burbank', a later sport of 'Burbank's Seedling', was not particularly susceptible to late blight might have been an achievement at its highest level (Inglis et al., 1996) (Table 1). Although it is often said that no resistance to 
Table 1. Area under the disease progress curve (AUDPC) on exposure to a field source of late blight (Phytophthora infestans) pathotypes identified after 1990 in Mount Vernon, WA. ${ }^{z}$

\begin{tabular}{lcccc}
\hline Cultivar & AUDPC 1993 & Significance & AUDPC 1994 & Significance \\
\hline Elba & 529 & $\mathrm{a}^{\mathrm{y}}$ & 135 & $\mathrm{a}$ \\
Kennebec & 748 & $\mathrm{~b}$ & 247 & $\mathrm{ab}$ \\
Ranger Russet & 1,101 & $\mathrm{bc}$ & 389 & $\mathrm{bc}$ \\
Russet Burbank & 1,035 & $\mathrm{~b}$ & 650 & $\mathrm{~d}$ \\
White Rose & 1,060 & $\mathrm{bc}$ & 834 & $\mathrm{de}$ \\
Shepody & 1,169 & $\mathrm{~cd}$ & 807 & $\mathrm{~cd}$ \\
Superior & 1,516 & $\mathrm{f}$ & 1,079 & $\mathrm{ef}$ \\
Russet Norkotah & 1,214 & de & 1,424 & $\mathrm{~g}$ \\
Hi Lite Russet & 1,388 & ef & 1,456 & $\mathrm{~g}$ \\
\hline
\end{tabular}

${ }^{\mathrm{z}}$ Clones are ranked from most to least resistant. Russet Burbank is less resistant than Elba but more resistant than Superior, Russet Norkotah, and Hi Lite Russet. Table extracted from Inglis et al. (1996).

${ }^{y}$ AUDPC values not sharing a letter are significantly different at $P<0.05$ according to analysis of ranked AUDPC values and a least significant difference test.

late blight was present in varieties of the day in 1845 nor in varieties released for more than three-fourths of a century afterward (Spooner et al., 2005), modern studies place 'Russet Burbank' in an intermediate susceptible status of resistance, relative to many other potato varieties. Not a matter for superlatives, neither resistant nor very susceptible, it and its relatives may have been notable for a greater, albeit slight, abatement of disease than that offered by any other cultivar of the time. Therefore, the overwhelming use of 'Early Rose', 'Burbank's Seedling's' immediate maternal ancestor, as a parent in breeding programs in Europe and North America may have had a basis in a conspicuous ability to transmit some resistance to late blight to the progenies (Reader, 2008).

This could explain the longevity and international dissemination of 'Early Rose', which was used extensively in breeding in Europe. In fact, it is difficult to find a pedigree that does not include 'Early Rose' as an ancestor in the early 20th century (Plaisted and Hoopes, 1989).

At the time, breeding of new potato varieties was of intense commercial interest to a few private breeders. It was customary to harvest open-pollinated berries from field-grown plants; hence, the pedigrees often only indicated the plant from which the berries were taken. Formal trials really did not exist and much of the description of a cultivar was hearsay, rarely with actual yields included. Keeping quality and culinary traits on boiling were foremost in the minds of the potato cultivar merchants. A bushel of seed of a new cultivar could sell for $\$ 50, \$ 900$ in today's currency (Best, 1870). Burbank decided to relocate to the West and needed traveling funds. He offered his clone to J.H.J. Gregory, a successful seedsman, for $\$ 500$ in 1873 . Gregory countered with $\$ 150$, which Burbank accepted disappointedly. Gregory generously named the clone 'Burbank's Seedling'. It appeared in the Gregory Seed Catalog in 1880 (Fig. 1). However, by 1920, it was no longer part of the Gregory Seeds offerings. Now in California, Burbank became remorseful of his sale to Gregory and sent a letter asking for greater remuneration. Gregory was quite direct in his response:

"My Dear Sir,

I have given you great fame by attaching your name to the potato and spread- ing it through the length and breath (sic) of the land. I purchased the Early Ohio at just about the same price I gave you for your seedling, did not give the originator's name to it, and have made greater sale of this than the Burbank.

As to the profit of selling potatoes in my business, with the cost of advertising and handling and loss by freezing and the filling out of orders comes with the opening of spring, just when we are heel over head with filling seed orders, causing us such a week behind hand I have half resolved more than once to(forsake) the whole potato business as unprofitable and a great nuisance You mistake in inferring that all this notoriety upon Burbank means money for me. It rather means fame for you. The more generally it is advertised, the more completely it is taken out of my hands.

I have stated the facts in the case and now enclose 25 dollars; for whatever I may write I know you will feel that some recompense is owed you." (Smith, 2009; Worrell, 2013)

Gregory had allowed Burbank to keep 10 tubers, which he used to start the cultivar in California. It spread on the west coast of North America where in 1914 it was stated to be worth $\$ 17$ million (Burbank, 1914). There is no evidence that 'Burbank's Seedling' was remunerative to Burbank despite the potential. It was a casualty to its ready vegetative propagation without legal means to recover royalties. Luther Burbank himself attributed the discovery of a russet skin mutant to Lou Sweet, a Colorado farmer, in 1914 (Burbank, 1914). However, it appears to be clear now that the russet sport was discovered earlier and called 'Netted Gem' (Bethke and Donnelly, 2014). Newspaper articles and seed catalogs place this in the year 1895. It was officially introduced in 1902 in the L.L. Mays seed catalog. Today the name 'Netted Gem' is used in Canada and 'Russet Burbank' in the United States and elsewhere. Eventually 'Burbank's Seedling' disappeared and 'Russet Burbank' increased in acreage, especially in the Intermountain West.

'Russet Burbank' found market acceptance heretofore unknown in potato cultivars.
In the Pacific Northwest, 'Russet Burbank' comprised $85 \%$ of the crop in Washington State, destined largely for processing.

Ray Croc, who undertook the expansion of McDonald's restaurants on a franchise model, started with one restaurant in San Bernardino, CA. He made an interesting discovery early in the process that proved essential to McDonald's French fries' reputation for excellence. First he determined that 'Russet Burbank' potatoes needed to sit and slightly dehydrate after delivery. Second, he found that fries were most appealing if they went through a two-step cooking process. The fries were half-cooked in hot oil and allowed to sit. The second step could be a short oil fry that imparted appropriate texture, taste, and unique mouth feel. All of this was done with 'Russet Burbank' as the model raw product. Continuous use of 'Russet Burbank' ensured exclusive preference for it as the raw product that most frequently performed the best. Processing innovations were always accomplished on 'Russet Burbank'. At first Ray Croc manufactured his once-cooked product, shipped in his raw potatoes, and stored on site (Croc, 1985). He found a willing industrial partner, J.R. Simplot Company, which pre-cooked the fries and sent them frozen in easily storable boxes to the restaurants. So successful was this that the brand McDonald's became synonymous with the most delicious French fries in the business. Ray Croc eventually bought out the McDonald Brothers and presided over the expansion of the McDonald's brand with construction of tens of thousands of new restaurants on a franchise model (CNBC, 2007; Croc, 1985). Today almost all quick service restaurants receive parfried frozen fries from potato processors, which the restaurants finish off with a second fry. Today $33 \%$ of McDonald's sales are French fries, estimated at 7 billion pounds per year. A highly trained tasting team tries out new varieties every year, and the lack of new recommendations characterizes a static situation, which protects 'Russet Burbank's' retention of such a large portion of the market (Love, 1995). A cultivar acceptable as a McFry ${ }^{\circledR}$ must perform in a narrow range in the following list of characters:

1. Crispness;

2. Color;

3. Texture external crusty surface, internal soft but not mushy;

4. Optimum absorption of oil. McDonald's has switched to a healthier Canola ${ }^{\circledR}$ vegetable oil for frying, the result of close collaboration with Cargill researchers (Cargill, La Crosse, WI);

5. Percent limp units (or fries that have lost their stiffness and become soft) at a specified time after frying;

6. Retention of freshly fried taste and texture after a specified number of minutes postfry;

7. A mix of strip lengths that occupy a certain volume and stay below a specified weight. Strips that are similar in 


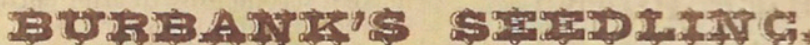

This, like the Early Ohio, is a seedling of Early Rose, but is of Massachusetts origin. ['nlike its parent it is $\pi$ hite skinned. It has yielded 435 bushels to the acre. Planted side by side with Eiarly Rose, New York Late Rose, Peerless and Brownell's Beauty, it has exeelled them all in yield. In beauty of form it is unexcelled, the proportions being all that tan be desired, and is never hollow liearted. It has the good characteristic of yielding almost no small potatoes; while but five-sixths of the Early Rose, growing side by side, were of market size, of the Burbank fortynine fiftieths were marketable. It has but few eyes, which are sunk but little below the surface. In quality it is fine grained, of excellent flavor eitlier boiled or baked, is dry and floury, in fine is all that can be desired. It ranks between the very early and very late varieties. The best results have been obtained on the saudy loams of river bottoms.

In brief, the argument for senting ont the new seedling is as follows: 1st, its exceptionally great

productiveness ; $2 d$, the first class quality of the
potato $: 3 d$, the capital trait for market, that it produces almost none of unmarketable size ; 4 th, its laardy vigor ; 5th, it

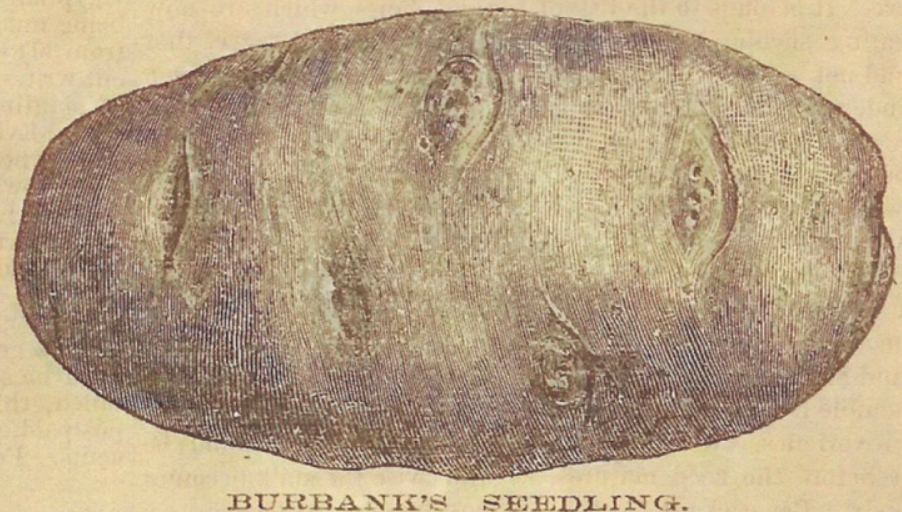
does not grow hollow hearted even when weighing over a pound to a single potato; fith, the proportions and appearance are so attractive it will draw the attention of marketmen. In many sections the Burbank has become the standard late potato.

"Last April I purehased of you one barrel of Burbank's Seedlings. Considering the dry season the yield was remarkably large. I dug 22 hushels of potatoes of superior quality." H. it. MANCHESTER. Paincerville, Ohio.

"The Burbank's Seedling protatoes are aw:ay ahead, for yelding, of anything I ever sitw. I'lanted by the side of others, with the same enltivation, it yielded three bundreil fold more tham any other kind excepting the loummore aud Excelsior. I slould lase made money to have pais the Dunmore and Excelsior. I should have made money to have nai \$20 per bushel last year, aud planter all Burbank's Seedling. From the one pound you sent me I raised, without ituy manure or any fertilizers

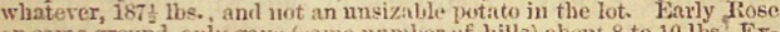
on same ground, only gave (same number

H. O. Batzer, Hammomils, Pa.

"The 15 llss if Burbank's Seeriling bonght of you, yiellerl from the single peck 16! bushels of large potatoes, uusuripassed in beauty and quality. No cure or manuring was given then more tlan the other parts of the field, except they were eut finer."
Madhury, $N, H$.

N. C. SNELL.

"Now as to the Burbauk's Seedling, the season has been unfaroralle, and the grasshoppers kiliecl them before they were matured, but for all that, they gave good satisfaction; they realized at the rate of 420 hushels to the acre, aud gs per cent. marketihle potatoek. I consider tlicu a intato of rave excellowee as a late variety. Little sioure, excel

-J. Is P'ERKIYYs.
The Burbauk Seedling ras planted with all my otler new sorts, and so far as a single trial is concerned, lias beat them all hanclsomely in ield, appearanes and quality, the tluree great essentials in a potato. Rome, Oneida Co., N. Y. Josath.s Tucots.

I have tested orer a thousanil rarieties of potatoes but the Burbank oxcels them all, growing the handsomest potatues I ever s:aw, while their quality was fully equal to their looks. A.MBRW LACKEY.

Mr. IAs. J, II. Guetiony : Sir,-From the barrel of Burbauk Seedlings you sent me I raised 153 bushels of splendid potatoes. They beat any thing $I$ ever satv.

Suratogu springs, N. Y.

\section{WHITE ROSE POTATO.}

Tuber of gool size, not too large, of good market shape ; quality excellent. Skin and flesh of a remarkably clear white, so that when dug they look as though made of wax. The vines are exceptionally stout and vigorous. The White Rose is a late variety and a capital cropper. Plant early in the soason.

=

\section{PRICE LIST OF POTATOES.}

\begin{tabular}{|c|c|c|c|c|c|c|c|c|c|c|c|c|c|}
\hline & $\begin{array}{l}\text { Dof. } \\
\text { exp. }\end{array}$ & $\begin{array}{l}\text { bo'ls } \\
\text { exp. }\end{array}$ & $\begin{array}{l}\text { peck } \\
\text { exp. }\end{array}$ & $\begin{array}{l}25 \text { eyes } \\
\text { mail. }\end{array}$ & $\begin{array}{l}1 \mathrm{lh} . \\
\text { mail. }\end{array}$ & $\begin{array}{l}3 \mathrm{lb} \text {. } \\
\text { mail. }\end{array}$ & & $\begin{array}{l}\text { bbl. } \\
\text { exp. }\end{array}$ & $\begin{array}{l}\text { bish } \\
\text { exp. }\end{array}$ & $\begin{array}{l}\text { leck } \\
\text { exp. }\end{array}$ & $\begin{array}{l}25 \text { eyes } \\
\text { mitil. }\end{array}$ & $\begin{array}{l}1 \mathrm{ll} \text {. } \\
\text { mail. }\end{array}$ & $\begin{array}{l}3 \mathrm{lb} \text {. } \\
\text { maril. }\end{array}$ \\
\hline & & & & & in & & Beauty of Hebron & +00 & 2.00 & 7.5 & 50 & 0 & 1.00 \\
\hline $\mathrm{Ne}$ & & 2. & & & 5 & & Ohio ....... & 3.75 & 1.88 & 75 & & & 1.00 \\
\hline edfing. I & 5. & 250 & 1.0 & 5 & 50 & 1.00 & STedl: & & & & 0 & & .00 \\
\hline . New. & & 2.25 & 7 & & 50 & & $\cdots$ & 3.75 & 1.88 & & & & .00 \\
\hline earl. Ne & 4.5 & 2.25 & 75 & 50 & $\widetilde{50}$ & 100 & mont...... & & 17 & & & & .00 \\
\hline$\cdots$ & 4.1 & 200 & 75 & 50 & 50 & 1.0 & Breese's No. 6, or Peerless.. & 3.25 & 1. 75 & 13 & & & 1.00 \\
\hline liss' Tri & 50 & 2.50 & 1.00 & 50 & 50 & 1.00 & Early Rose............ & 3.00 & $1 . \overline{0} 0$ & 75 & 50 & 50 & 1.00 \\
\hline
\end{tabular}

Fig. 1. Gregory's announcement of the Burbank Seedling in his seed catalog in 1880. Kindly provided by Shari Kelley Worrell, J.H.J. Gregory's great great granddaughter and author of "Remembering James J.H. Gregory: The Seed King, Philanthropist, Man,” 2013.

length tend to fill the serving container with too high a weight; and

8. Retention of good fry quality after 8 months of storage.

At this writing only four varieties are acceptable for the McFry brand: 'Russet Burbank', 'Shepody', 'Ranger Russet', and 'Umatilla Russet’ (CNBC, 2007).

\section{CONCLUSIONS}

Luther Burbank's early success with 'Burbank's Seedling' certainly fed his confidence that he was following the right route to fame. The domination of 'Russet Burbank' of the North American market makes Luther Burbank the most successful breeder of potatoes in history. In present-day terms, 'Russet Burbank' is worth $\$ 1.5$ billion annually. This is true despite decades of decline in acreage. In Washington State for instance, 'Russet Burbank' has declined from $82 \%$ to $45 \%$ of the acreage from 1990 to 2011 (Pavek and Knowles, 2013; USDA/NASS, 2012) (Fig. 2). In addition, the pattern of variation in the progenies coming from the fruit of an 'Early Rose' plant reinforced his philosophy about revealing genetic variation. The variation accumulated over many generations of sexual reproduction was hidden only to be unfettered by hybridization. "We have observed that the latent qualities of diverse strains of ancestors are permitted to come to the surface and make themselves manifest once the tendency to relative fixity has been broken by hybridization" (Burbank, 1914). Certainly this contention has proven useful in vegetatively propagated crops, which when perpetuated vegetatively only change slightly over time as a result of somatic "sports." Sexual reproduction reveals the highly heterozygous composition underlying an otherwise unvarying line of clonal reproduction. After looking at another half million seedlings, Burbank could state another 


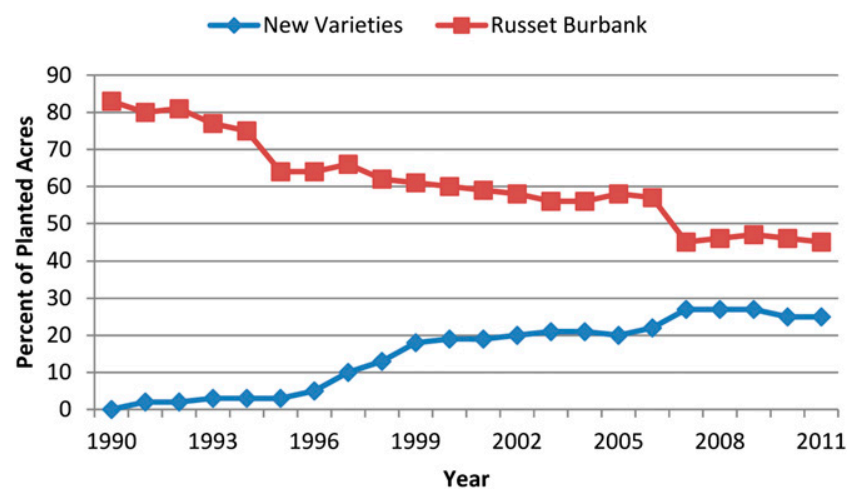

Fig. 2. Decline in percentage of total potato acreage planted to 'Russet Burbank' compared with new varieties from 1990 to 2011 .

breeding truism from experience; sexual reproduction rarely produces a progeny as good as a highly successful clonally propagated parent (Burbank, 1914). 'Russet Burbank' always has been very hard to beat. Donnelly et al. (2014) have concluded using the most sensitive test available (Li et al., 2008) that 'Early Rose' and 'Burbank's Seedling' were derived from outcrosses to other unidentifiable pollen parents.

Luther Burbank's lifelong belief that 'Burbank's Seedling' was a self of 'Early Rose' was not correct. He made crosses of 'Burbank's Seedling' with a red-skinned potato brought in from Chile, reportedly, but nothing commercially viable emerged (Burke, 2007). What is clear is that his experience with potato and the discovery of 'Burbank's Seedling' informed one of his first principles in his philosophy of plant breeding. Nearly all of his work was done with clonally propagated species. It is well known now that sexual crosses yield highly variable progenies as a result of the inherent heterozygosity in clonally propagated species. If one were to pick out the single dogma that Burbank resorted to again and again, it was to make crosses to come up with new combinations. His ability to conceive of the new types that were needed in the market- place and in a single-minded way to select for these was the rarest of gifts.

\section{Literature Cited}

Best, G.W. 1870. Best's potato book. Reprint Repressed Publishing, Provo, UT.

Bethke, P.C. and D.J. Donnelly. 2014. The origin of Russet Burbank (Netted Gem), a sport of Burbank. Amer. J. Potato Res. Abstracts of 98 annual meeting of the Potato Society of America, p. 77. Spokane, WA, 27-31 July 2014.

Bourke, A. 1993. The visitation of God? The potato and the great Irish famine. Lilliput Press Ltd., Dublin, Ireland.

Burbank, L. 1914. The potato itself-Who will improve it further? In: Whitson, J., R. John, and H.S. Williams (eds.). Luther Burbank: His methods and discoveries and their practical application. 12 Volumes. Luther Burbank Press, New York, NY.

Burke, R.M. 2007. An intimate history of Bodega Country and the McCaughey family. Tomales Regional History Center, Tomales, CA.

CNBC. 2007. Big Mac: Inside the McDonald's empire. Television documentary on DVD.

Croc, R. 1985. Grinding it out: The making of McDonald's. St. Martin's Paperback Books, New York, NY.

Donnelly, D.J., A.T.K. Nassar, S. Kubow, Y.N. Leclerc, X.-Q. Li, M. Heroon, T. Molen, B. Bizimungu, J. Bamberg, and M. Martin. 2014. History and origin of Russet Burbank
(Netted Gem) a sport of Burbank. Amer. J. Potato Res. 91:594-609.

Dreyer, S. 1993. A gardener touched with genius: The life of Luther Burbank. Luther Burbank Home and Gardens, Santa Rosa, CA.

Goodrich, C.E. 1863a. The origination and test culture of seedling potatoes. Transcripts of the New York State Agricultural Society 23:89-102.

Goodrich, C.E. 1863b. The potato: Its diseaseswith incidental remarks on its soils and culture. Transcripts of the New York State Agricultural Society 23:103-134.

Inglis, D.A., D.A. Johnson, D.E. Legard, W.E. Fry, and P.B. Hamm. 1996. Relative resistances of potato clones in response to new and old populations of Phytophthora infestans. Journal of Plant Disease 80:575-578.

Kelly, J. 2012. The graves are walking: The great famine and the saga of the Irish people. Henry Holt and Company, New York, NY.

Li, X.-Q., M. Heroon, S.E. Coleman, A. Sullivan, M. Singh, L. Ward, S.H. De Boer, T. Zhang, and D.J. Donnelly. 2008. A simplified procedure for verifying and identifying potato cultivars using multiplex PCR. Can. J. Plant Sci. 88:583-592.

Love, J.F. 1995. McDonald's: Behind the golden arches (revised edition). Bantam Books, New York, NY.

Pavek, M.J. and N.R. Knowles. 2013. 2012 Potato cultivar yield and post-harvest quality evaluations. Department of Horticulture and Landscape Architecture, Washington State University. Mar. 2014. <http://www.potatoes.wsu.edu/>

Plaisted, R.L. and R.W. Hoopes. 1989. The past record and future prospects for the use of exotic germplasm. Amer. Potato J. 66:603-627.

Reader, J. 2008. Potato: A history of the propitious esculent. Yale University Press, New Haven, CT.

Salaman, R.N. 1949. The history and social influence of the potato. Cambridge University Press, Cambridge, UK.

Smith, J.S. 2009. The garden of invention: Luther Burbank and the business of breeding plants. The Penguin Press, New York, NY.

Spooner, D.M., K. McLean, G. Ramsay, R. Waugh, and G.J. Bryan. 2005. A single domestication for potato based on multilocus AFLP genotyping. Proc. Natl. Acad. Sci. USA 120:14694-14699.

USDA/NASS. 2012. Potatoes-2011-Summary. Jan. 2014. <http://www.nass.usda.gov>.

Worrell, S.K. 2013. Remembering James J. H. Gregory: The seed king, philanthropist, man. Family Heritage Publishers, Murray, UT. 